\title{
POLA KECEMASAN PEREMPUAN PENYINTAS KEKERASAN DALAM PACARAN: KAJIAN PERSPEKTIF BEHAVIORAL
}

\author{
Sofyan Aye ${ }^{1}$ Sutarto Wijono ${ }^{2}$ Arianti Ina Restiani Hunga ${ }^{3}$ \\ Email: sofyanaye93@gmail.com ${ }^{1}$ \\ Program Studi Magister Sains Psikologi Fakultas Psikologi Universitas Kristen Satya \\ Wacana $^{1}$ Universitas Kristen Satya Wacana ${ }^{2,3}$
}

\begin{abstract}
Abstrak
Tujuan review ini adalah untuk mendeskripsikan perspektif behavioral teknik desensitisasi sistematis, dan bagaimana terapi ini dapat menjadi terapi yang tepat untuk memulihkan kecemasan penyintas yang mengalami kekerasan dalam berpacaran. Metode pengumpulan data bersumber dari jurnal elektronik dan buku yang relevan dengan kajian. Pertama, dibahas mengenai kasus kekerasan dalam berpacaran di Indonesia. Selanjutnya, dibahas mengenai teknik desensitisasi sistematis, dan hasil-hasil penelitian sebelumnya mengenai teknik desensitisasi sistematis. Berdasarkan kajian ini, teknik desensitisasi sistematis terbukti efektif menurunkan tingkat kecemasan pada individu. Karena penyintas kekerasan dalam berpacaran juga mengalami kecemasan, maka diharapkan pendekatan teknik desensitisasi sistematis dapat digunakan sebagai metode pemulihan untuk menurunkan tingkat kecemasan. Kesimpulan kajian ini, agar dapat dilakukan pilot study untuk menguji efektifitas teknik desensitisasi sistematis dalam konteks kekerasan dalam berpacaran di Indonesia.
\end{abstract}

Kata kunci: Review Literatur, Penyintas Kekerasan dalam Pacaran, Perspektif Behavioral, Teknik Desensitisasi Sistematis.

\section{PENDAHULUAN}

World Health Organization (2013), melakukan survei secara menyeluruh di kawasan Asia Tenggara tentang kekerasan terhadap perempuan (KTP) menunjukkan bahwa kawasan Asia Tenggara menempati presentase yang tertinggi, yaitu sebesar $37,7 \%$, kemudian wilayah Mediterranian Timur sebesar $37 \%$, dan wilayah Afrika sebesar 36,6\%. Baldwin (2012), memaparkan dalam penelitian yang dilakukan oleh Thomson Reuters Foundation terhadap 63 negara, temuannya menunjukan Indonesia merupakan negara terburuk ketiga kekerasan terhadap perempuan setelah India dan Arab Saudi. Selain itu, adapun data yang diperoleh dari Thomson Reuters
Foundation (2017), yang dilaporkan bahwa Jakarta masuk kategori kota terburuk nomor sembilan di dunia mengenai kekerasan terhadap perempuan baik secara fisik maupun seksual.

Data dari Komisi Nasional (Komnas) anti kekerasan terhadap perempuan menjelaskan di Indonesia pada tahun 2011 terdapat 119.107 kasus kekerasan terhadap perempuan (Komnas Perempuan 2012). Jumlah ini meningkat menjadi 216.156 kasus KTP pada tahun 2012 (Komnas Perempuan, 2013). Pada tahun 2013, kasus kekerasan terhadap perempuan juga terjadi peningkatan dengan jumlah 279.688 kasus (Komnas Perempuan, 2014). Pada tahun 2014 sampai pada tahun 2017, kasus kekerasan 
terhadap perempuan masih tetap meningkat yaitu dari 293.220 kasus menjadi 348.446 kasus KTP (Komnas Perempuan, 2015, 2016, 2017, 2018).

Kekerasan dalam berpacaran (KDP) menurut, The American Psychological Association (dalam Warkentin, 2008) adalah kekerasan psikologis dan fisik yang dilakukan oleh salah satu pihak dalam hubungan pacaran, yang mana perilaku ini ditujukan untuk memperoleh kontrol, kekuasaan, dan kekuatan atas pasangannya. Sementara itu, The University of Michigan Sexual Assault Prevention and Awareness Center mendefinisikan kekerasan dalam pacaran (KDP) sebagai tindakan kesengajaan yang dilakukan dengan menggunakan taktik untuk melukai dan paksaan fisik dengan meksud untuk memperoleh dan mempertahankan kekuatan serta kontrol terhadap pasangannya (Murray, 2007). Murray juga menambahkan, perilaku kekerasan itu tidak dilakukan atas paksaan orang lain melainkan sang pelaku yang memutuskan sendiri untuk melakukan perilaku kekerasan, perilaku tersebut ditujukan agar sang korban tetap bergantung atau terikat dengan pasangannya (Murray, 2007).

Hasil penelitian terdahulu mengenai KDP ditemukan beberapa dampak negatif pada individu. Dampak pertama adalah kehamilan yang tidak di inginkan (KTD). Sinaga (2010), mengatakan bahwa di Indonesia diperkirakan ada 1 juta remaja yang hamil diluar nikah setiap tahun. Secara global, menurut World Health Organization (WHO, 2013b), terdapat 38\% kehamilan yang terjadi di dunia setiap tahun adalah KTD. Dampak kedua adalah timbulnya pernikahan usia dini. Pada tahun 2012 di Indonesia, persentase pernikahan kelompok usia yang tertinggi adalah kelompok berusia 15-19 tahun (Badan Pusat Statistik, 2012). Sementara itu, hasil penelitian dari UNICEF (2016), menunjukkan bahwa 1 dari 4 perempuan di Indonesia menikah dibawah usia 18 tahun. Lebih lanjut, Badan Pusat Statistik (2012), menyatakan salah satu penyebab terjadinya pernikahan di usia dini adalah kehamilan yang tidak diinginkan (KTD). Pernikahan di usia dini juga memiliki dampak negatif, karena menurut Santrock (2013), pada usia tersebut kondisi emosional remaja masih labil dan belum peka dalam situasi tertentu. Hal ini akan berdampak buruk bagi perkembangan psikologis dan emosional seseorang baik pada orang tua maupun anak yang akan mereka asuh (Santrock, 2013). Dampak ketiga adalah aborsi. Di Indonesia, perempuan yang melakukan tindakan abortus atau pembunuhan janin per tahun 
sudah mencapai 3 juta, angka yang tidak sedikit mengingat besarnya tingkat kehamilan di Indonesia (Daniaty, 2012). Secara psikologis, menurut World Health Organization (2013), bahwa pengalaman aborsi yang dilakukan oleh remaja putri dapat menjadi sebuah pengalaman traumatis, dan bahkan bisa lebih dari itu apabila prosedur aborsi tidak aman, maka dapat membahayakan nyawa remaja tersebut.

Sementara itu, Marcelina (2008), menjelaskan dampak psikologis yang terjadi pada perempuan penyintas kekerasan dalam berpacaran (KDP) adalah kecemasan, rasa bersalah, kekaburan identitas, kesedihan, depresi, dan rasa malu. Selain itu, penelitian oleh Ayu, Hakimi, dan Hayati (2012) ditemukan bahwa perempuan penyintas KDP juga mengalami gangguan psikologis, dalam penelitian tersebut terindikasi adanya perasaan cemas sehingga penyitas menjadi rendah diri, dan ketidak percayaan terhadap laki-laki. Begitu pun penelitian oleh Safitri dan Sama'i (2013) mengenai dampak kekerasan dalam pacaran, dalam penelitian mereka ditemukan bahwa penyintas KDP mengalami gangguan psikologis yang sangat serius. Tercatat ada beberapa jenis gangguan psikologis yang dialami penyintas kekerasan dalam berpacaran, salah satunya adalah gangguan kecemasan. Menurut Rachmayanie, Sari, \& Sulistiyana (2016), kecemasan adalah sebuah pengalaman negatif yang sangat menyakitkan yang muncul karena faktor ketegangan dalam diri seseorang maupun karena faktor ketegangan dari luar yang dikuasai oleh susunan saraf otonom.

Berdasarkan uraian diatas, peneliti memandang gangguan kecemasan yang dialami penyintas KDP perlu dipulihkan dengan terapi behavioral. Martin \& Peer (2015), mengatakan gangguan-gangguan psikologis seseorang dapat ditangani lewat terapi behavioral, salah satu penanganan yang efektif pada gangguan psikologis dalam terapi behavioral adalah teknik desensitisasi sistematis. American Psychological Association (APA) Presidential Task Force on EvidenceBased Practice juga telah merekomendasi mengenai teknik ini dalam website khusus

(www.psychologicaltreatments.org) yang dibuat oleh divisi 12 klinis APA atau bagian Masyarakat Psikologi Klinis, dalam website tersebut menginstruksikan setiap psikolog klinis harus menggunakan penanganan yang didukung secara empiris (EST: empirically supported treatments), yaitu penanganan yang terbukti efektif dalam percobaan klinis yang terkontrol. Menurut situs ini, beberapa penanganan 
yang telah di uji terbukti efektif yang di dalamnya termasuk terapi behavioral dengan teknik desensitisasi sistematis, (APA Presidential Task Force on Evidence-Based Practice 2006, dalam Martin \& Peer, 2015).

Teknik desensitisasi sistematis adalah salah satu terapi behavioral yang paling luas digunakan. Martin \& Peer (2015) mengatakan teknik desensitisasi sistematis adalah salah satu teknik yang paling luas digunakan dalam terapi behavioral. Teknik ini, menurut Wolpe (dalam Martin \& Peer, 2015), dapat diterapkan secara efektif pada berbagai situasi penghasil kecemasan yang mencakup situasi interpersonal, ketakutanketakutan yang digeneralisasi, kecemasankecemasan neurotik, serta impotensi dan frigiditas seksual. Aspek-aspek dalam teknik desensitisasi, menurut Wolpe, adalah ketakutan, kecemasan, dan perilaku maladaptif (Martin \& Peer, 2015). Adapun penelitian terdahulu yang telah membuktikan menurunkan tingkat kecemasan, seperti penelitian oleh Astuti (2018), mengenai pemulihan kecemasan dalam berkomunikasi. Hasil penelitiannya menunjukan bahwa teknik desensitisasi dapat menurunkan tingkat kecemasan dalam berkomunikasi. Sementara itu, penelitian dari Firosad, A. M., Nirwana, H., \& Syahniar, S. (2016) mengenai fobia mahasiswa, hasil penelitian juga terbukti bahwa teknik desensitisasi sistematis secara signifikan menurunkan fobia mahasiswa. Karena kasus kekerasan dalam berpacaran berdampak pada kecemasan, maka teknik desensitisasi sistematis juga diharapkan dapat digunakan sebagai salah satu intervensi pada korban yang mengalami KDP. Tujuan penelitian ini untuk mendeskripsikan mengenai perspektif behavioral dengan teknik desensitisasi sistematis dan menjelaskan bagaimana teknik ini dapat menjadi sebuah terapi yang tepat untuk memulihkan kecemasan pada penyintas yang mengalami kekerasan dalam berpacaran.

\section{METODE PENELITIAN}

Metode yang digunakan dalam penelitian ini adalah studi pustaka. Menurut Syaibani (2012), studi pustaka adalah usaha yang dilakukan oleh peneliti untuk mengumpulkan segala informasi yang sesuai dengan topik atau masalah yang akan atau sedang diteliti. Informasi tersebut berupa buku-buku ilmiah, laporan penelitian, karangan-karangan ilmiah, tesis dan disertasi, peraturan-peraturan, ketetapan-ketetapan, buku tahunan, ensiklopedia, dan sumber-sumber tertulis baik tercetak maupun elektronik. Ciri utama studi kepustakaan menurut Zed 
(dalam Azizah, 2017) meliputi: 1) Peneliti berhadapan langsung dengan teks atau data angka dan bukan dengan pengetahuan langsung dari lapangan atau saksi mata berupa kejadian, orang, atau benda-benda lainnya: 2) Data pustaka bersifat siap pakai artinya peneliti tidak pergi kemana-man kecuali berhadapan langsung dengan bahan sumber yang sudah tersedia di perpustakaan: 3) Data pustaka umumnya adalah sumber sekunder, artinya peneliti memperoleh bahan dari tangan kedua dan bukan data orisinil dari tangan pertama di lapangan: 4) Kondi Kondisi data pustaka tidak dibatasi oleh ruang dan waktu.

\section{HASIL DAN PEMBAHASAN}

\section{Kajian Kekerasan dalam Pacaran}

Menurut Breiding, Basile, Smith, Black, \& Mahendra (2015), kekerasan dalam pacaran adalah segala tindakan penyerangan fisik, penyerangan seksual, stalking, dan penyerangan psikologi yang dilakukan oleh pasangan intim secara paksaan. Pasangan intim yang dimaksud, menurut Pratiwi (2017), adalah individu yang memiliki kelekatan emosional, yang terkoneksi secara teratur baik fisik maupun perilaku seksual pada pasangannya, dan biasanya mengetahui tentang aktivitas kehidupan sehari-hari satu sama lain. Penjelasan yang sama juga disampaikan oleh Tutty, dkk (dalam Santoso, 2015), menurut mereka, kekerasan dalam pacaran adalah sebuah serangan baik seksual, fisik, maupun psikologis yang dilakukan dengan sengaja oleh salah satu pasanagan dalam hubungan pacaran.

Sementara itu, The University of Michigan Sexual Assault Prevention and Awareness Center di Ann Arbor (dalam Santoso, 2015), mendefenisikan kekerasan dalam berpacaran merupakan suatu tindakan kesengajaan yang dilakukan kepada pasangan dengan menyalahkan, mengisolasi, memanipulasi, mengancam, menghina, serta melakukan tindakan kekerasan verbal, emosional, seksual, hingga kekerasan fisik. Hasil penelitian Ariestina, (2009), menjelaskan penyitas seringkali tidak menyadari ketika mengalami kekerasan oleh pacar karena cenderung menganggap perlakuan pacarnya adalah bukti rasa sayang, perhatian, dan cinta. Berdasarkan pengertian diatas maka dapat dipahami bahwa kekerasan dalam pacaran merupakan serangan yang dengan sengaja dilakukan oleh seorang terhadap pasangannya dalam relasi berpacaran.

Bentuk kekerasan dalam pacaran adalah kekerasan fisik, kekerasan psikis, kekerasan seksual, dan kekerasan ekonomi (Breiding dkk., 2015; 
Poerwandari, 2004; Yayasan Puli, 2015).

Kekerasan fisik adalah perbuatan atau pemaksaan secara fisik yang mengakibatkan rasa sakit, luka di tubuh, cacat fisik, hingga kematian. Kekerasan psikis adalah penggunaan komunikasi verbal ataupun non verbal yang bermaksud untuk membahayakan orang lain secara mental atau emosional dan atau kontrol yang berlebihan terhadap orang lain (Breiding dkk, 2015). Kekerasan seksual adalah segala upaya bentuk aktivitas seksual atau perilaku lain yang bertujuan untuk menyerang seseorang terkait seksualitasnya dengan cara memaksa oleh orang lain dalam berbagai situasi. Perilaku kekerasan seksual yaitu serangan fisik untuk melukai alat seksual ataupun serangan psikologi yang diarahkan pada penghayatan seksualitas. Kekerasan ekonomi adalah perbuatan yang mencakup pemanfaatan seseorang secara materi, misalnya memaksa membiayai keperluan pacar, meminta uang secara paksa, dan mengontrol tabungan pasangan (Yayasan Puli, 2015). Selain itu, individu yang mengalami kekerasan, menurut Poerwandari (2004), dapat dikategorikan dalam bentuk pengalaman kekerasan secara berbeda, tergantung dari sudut pandangnya. Kekerasan dapat atau sering berlapis-lapis yang diterima oleh korban kekerasan (Poerwandari, 2004).

Dampak kekerasan dalam berpacaran berpengaruh pada ganguan pskologis dan perilaku seseorang. Pernyataan ini didukung dalam hasil penelitian oleh DeGenova,( 2008); Safitri \& Sama'i,(2013), yang menjelaskan bahwa individu yang mengalami tindak kekerasan selama berpacaran dapat berakibat pada terganggunya proses pikiran, perasaan, dan perilaku korban. Sementara itu, secara psikologis, perempuan korban kekerasan dalam berpacaran (KDP) juga dapat mengalami gejala stres, depresi, gangguan kecemasan, kesulitan berkonsentrasi, insomnia, dan memiliki penghargaan diri yang rendah terhadap dirinya sendiri Safitri (2013). Marcelina (2008) menambahkan bahwa perasaan malu terhadap diri sendiri juga sering dialami perempuan korban KDP. Maka dari itu, menurut Pratiwi (2017), self-esteem yang rendah akan menjadi faktor penguat bagi individu untuk terus bertahan dalam siklus kekerasan dari pasangannya.

\section{Pola Kecemasan Personal dalam} Konteks Kekerasan Secara Umum

Menurut Rachmayanie, Sari, dan Sulistiyana (2016), pola kecemasan personal adalah bagian dari bentuk emosi individu yang terjadi karena perasaan 
terancam oleh sesuatu, biasanya ancaman tersebut adalah objek atau situasi yang tidak begitu jelas. Kecemasan dengan intensitas yang wajar dapat dianggap bernilai positif tetapi apabila intensitas kuat akan menimbulnya kerugian pada keadaan fisik dan psikis individu yang bersangkutan. Kecemasan merupakan sebuah masalah psikis yang dapat menyebabkan rasa khawatir karena persepsi negatif individu terhadap sebuah objek atau situasi tertentu (Ayu Km, Nym Dantes, \& Sulastri, 2013). Selanjutnya meraka mengatakan kecemasan adalah semacam kegelisahan, kekhawatiran dan ketakutan terhadap sesuatu yang tidak jelas.

Sementara itu, Racmayanie dkk (2016), menambahkan pola kecemasan personal merupakan suatu pengalaman menyakitkan yang timbul karena ketegangan-ketegangan dalam diri yang disebabkan dari ketegangan yang timbul akibat dorongan dari internal ataupun eksternal yang dikuasai oleh susunan urat saraf yang otonom. Menurut Freud (dalam Ayu dkk, 2013), menjelaskan timbulnya kecemasan personal akibat dari pemikiran yang kurang rasional sehingga membuat rasa khawatir dengan apa yang dihadapinnya. Freud menambahkan, kecemasan juga dapat ditimbulkan oleh kondisi kurang rileksnya tubuh dan pikiran saat menghadapi suatu persoalan.

Deffenbacher dan Hazeleus juga mengemukakan hal yang sama, menurutnya (dalam Rachmayanie dkk, 2016), ada beberapa hirarki penyebab kecemasan personal. Pertama kekhawatiran (Worry), merupakan pikiran negatif tentang dirinya sendiri, seperti saya lebih jelek dibandingkan dengan teman-temannya. Kedua emosionalitas (emotionality), merupakan reaksi dalam diri terhadap stimulus saraf otonom, seperti jantung berdebar, berkeringat dingin dan merasa tegang. Ketiga gangguan dan hambatan menyelesaian tugas (task generated interference), merupakan seseorang yang selalu mengalami kecenderungan tertekan karena selalu berpikir rasional dalam menyelesaikan tugas (Ghufron, \& Risnawati, 2010).

Secara umum, menurut Ghufron dkk (2010), faktor yang menyebab timbulnya kecemasan personal adalah faktor internal dan faktor eksternal. Faktor internal meliputi tingkat religiusitas yang rendah, rasa pesimis, takut gagal, pengalaman negatif masa lalu, dan pikiran-pikiran tidak rasional. Sementara faktor eksternal seperti kurangnya dukungan sosial. Jadi dapat dipahami, kecemasan personal adalah sebuah 
persepsi negatif oleh individu atau personal terhadap sesuatu yang belum diketahui kebenaranya, kecemasan dipengaruhi oleh dua faktor yaitu faktor internal dan faktor eksternal.

Penelitian mengenai kecemasan personal dengan topik kekerasan telah banyak dilakukan. Pratiwi (2017), mengatakan mengenai situasi kekerasan dalam pacaran akan berdampak buruk terhadap kesehatan mental para penyitas. Kesehatan mental dipahami sebagai rasa cemas atau panik, yang secara psikologis mencakup terganggunya pikiran, perasaan, dan merasa harga dirinya rendah. Pernyataan ini dikuatkan dengan beberapa penelitian (DeGenova, 2008; Safitri \& Sama'i, 2013) menjelaskan mengenai dampak kekerasan dalam pacaran seperti terganggunya proses pikiran, perasaan, yang berdampak terhadap perilaku penyitas. Penyitas akan mengalami konsep diri yang tidak stabil dan merasa harga dirinya (self-esteem) rendah. Self-esteem yang rendah merupakan bagian dari faktor penyebab penyitas sulit untuk keluar dari siklus kekerasan (Anguilar \& Nightingale, dalam Pratiwi, 2017).

Kekerasan dalam konteks seksualitas, juga memiliki dampak psikologis oleh penyitas seperti kecemasan dan gangguan psikologis lainnya. Beberapa hasil penelitian dari Levitan, Rector, Sheldon, Goering; Messman-Moore, Terri Patricia; Dinwiddie, Heath, Dunne, Bucholz, Madden, Slutske, Bierut, dan Statham menjelaskan mengenai kasus kekerasan seksual terhadap anak terdapat gangguangangguan psikologi terhadap penyitas kekerasan tersebut seperti panik atau cemas, pasca-trauma stress disorder, dan penyakit jiwa lainya, termasuk gangguan kepribadian, gangguan identitas disosiatif, kecenderungan untuk reviktimisasi dimasa dewasa, bulimia nervosa, dan cedera visik terhadap anak (dalam Maslihah, 2013). Selanjutnya penelitian oleh Matud (2005), mengenai The Psychological Impact of Domestic Violence on Spanish Women ditemukan bahwa kekerasan yang terjadi pada perempuan memiliki beberapa dampak psikologis salah satunya adalah kecemasan. Untuk lebih luas, menurut Williamas dan Frize (2005), penelitian mengenai Patterns of violent relationships, psychological distress, and marital satisfaction in a national sample of men and women juga ditemukan kecemasan bagi penyitas kekerasan.

Berdasarkan penjelasan diatas, maka dapat disimpulkan bahwa segala bentuk kekerasan yang dialami penyitas dapat menyebabkan gangguan-gangguan psikologis seseorang diantaranya 
kecemasan. Kecemasan merupakan bagian dari bentuk emosi individu yang terjadi karena perasaan terancam oleh sesuatu baik sebuah objek maupun situsasi tertentu. Secara umum, berdasarkan penjelasan diatas, penyebab terjadinya kecemasan personal terdiri dari faktor internal dan faktor eksternal. Faktor internal meliputi tingkat religiusitas yang rendah, rasa pesimis, takut gagal, pengalaman negatif masa lalu, dan pikiran-pikiran tidak rasional. Sementara faktor eksternal seperti kurangnya dukungan sosial.

\section{Perspektif Terapi Behavioral Teknik} Desensitisasi Sistematis

Pada tahun 1950-an banyak eksperimen yang dilakukan oleh psikolog dan terapis dalam mengembangkan setiap potensi yang ada didalam diri manusia. Salah satu dari sekian temuan baru yang ditemukan adalah pentingnya belajar pada manusia, untuk mendapatkan hasil belajar yang baik diperlukan reinforcement, dari hasil temuan tersebut sehingga temuan ini lebih menekankan pada dua hal penting yaitu learning dan reinforcement agar tercapainya suatu perubahan perilaku (behavior). Dalam perkembangannya, teori ini dienal dengan behavior therapy dalam kelompok paham behaviorisme. Istilah behavior pertama kali digunakan oleh Lindzey pada tahun 1954 dan kemudian dipernalkan oleh Lazarus pada tahun 1958 (Sanyata, 2012).

Steven Jay Lyn dan John P. Garske mengemukakan bahwa asumsi dasar dalam pendekatan behavioristi adalah (1) memiliki konsentrasi pada proses perilaku, (2) menekankan dimensi waktu here and now, (3) manusia berada pada perilaku maladaptif, (4) proses belajar merupakan cara efektif untuk mengubah perilaku maladaptif, melakukan penetapan tujuan pengubahan perilaku, (6) menekankan nilai secara empiris dan didukung dengan berbagai teknik dan metode (dalam Sanyata, 2012). Dalam penerapan teori behavioral, menurut Corey (2005) menjelaskan bahwa proses dalam dalam pendekatan behavioristik terdiri dari empat hal yaitu (1) tujuan terapis pada memfomulasikan tujuan secara spesifik, jelas, konkrit, dimengerti dan diterima oleh konseli dan konselor, (2) peran dan fungsi konselor atau terapis adalah mengembangkan keterampilan menyimpulkan, reflection, clarification, dan open-ended questioning, (3) kesadaran konseli dalam melakukan terapi dan partisipasi konselor ketika proses terapi berlangsung akan diberikan pengalamn positif pada konseli dalam terapi, dan (4) memberi kesempatan kepada konseli atas kerja sama dan 
harapan positif dari konseli yang akan membuat harapan terapis lebih efektif.

Pendekatan behavior merupakan sebuah usaha untuk memanfaatkan pengetahuan secara sistematis, teoritis, dan empiris yang dihasilkan melalui penggunaan metode yang efektif teruji dalam psikologi untuk memahami dan menyembuhkan pola perilaku abnormal. Pendekatan tingkah laku (behavioral) dapat digunakan dalam penyembuhan dari berbagai gangguan psikologi atau perilaku dari yang sederhana hingga yang kompleks baik individu maupun kelompok. Sedangkan tujuan pendekatan behavioral untuk menghilangkan tingkah laku yang salah atau yang tidak sesuai dan membentuk tingkah laku yang baru yang lebih baik (Sanyata, 2012). Pavlov mengungkapkan berbagai kegunaan teori dan tekniknya dalam memecahkan masalah tingkah laku (behavior) penyitas abnormal seperti hysteria, obsessional neurosis dan paranois (Sanyata, 2012). Teknik desensitisasi sistematis adalah salah satu terapi behavioral. Martin \& Peer (2015) mengatakan teknik desensitisasi sistematis adalah salah satu teknik yang paling luas digunakan dalam terapi behavioral.

Teknik Desensitisasi Sistematis dikembangkan oleh Joseph Wolpe pada tahun 1958. Menurut Wolpe, penanganan terhadap individu yang mengalami perasaan cemas dan fobia-fobia spesifik dapat di intervensi dengan teknik desensitisasi sistematis (Martin \& Peer, 2015). Ciri kecemasan yang menimbulkan sebuah ketakutan adalah suatu respon yang terkondisikan secara respon terhadap objek atau situasi yang ditakuti (Martin \& Peer, 2015). Ketakutan tersebut, menurut Wolpe, dapat dihapus dengan teknik desensitisasi sistematis. Desensitisasi sistematis adalah suatu teknik untuk menghapus atau mengurangi respon emosional yang menakutkan, mencemaskan, atau tidak menyenangkan melalui aktivitas-aktivitas yang bertentangan dengan respon yang menakutkan itu (Willis, 2004). Desensitisasi sistematis juga bisa digunakan untuk mengurangi maladaptif kecemasan yang dipelajari seperti fobia, dan juga dapat diterapkan pada masalah lain, misalnya kecemasan dan trauma (Firosad dkk, 2016). Penjelasan ini diperkuat dengan penelitian oleh Marfiati, (dalam Rachmawati, 2012), menjelaskan bahwa desensitisasi sistematis dapat digunakan untuk menghapus tingkah laku yang diperkuat secara negatif seperti kecemasan dan ketakutan, dengan cara memunculkan respon yang berlawanan dengan tingkah laku yang hendak di hapuskan itu. Artinya, respon-respon yang 
tidak dikehendaki dapat dihilangkan secara bertahap. Berdasarkan penjelasan dari beberapa parah ahli diatas, secara umum, dipahami bahwa teknik desensitisasi sistematis dapat membantu menghilangkan, melemahkan, dan mengurangi terhadap ketakutan, kecemasan, dan trauma seseorang.

Tujuan desensitisasi sistematis pada dasarnya untuk menghapus tingkah laku yang diperkuat secara negatif, dan ia menyertakan pemunculan tingkah laku dan respon yang berlawanan dengan tingkah laku yang hendak dihapuskan itu (Ayu, Dantes, \& Sulastri, 2013). Menurut Willis (2004), menjelaskan tujuan teknik desensitisasi sistematis adalah mengajarkan klien untuk memberikan respon yang tidak konsisten dengan kecemasan atau ketakutan yang dialami klien. Sedangkan menurut Firosad dkk, (2016), menjelaskan bahwa tujuan teknik ini mengajarkan klien untuk santai dan menghubungkan keadaan santai itu dengan membayangkan pengalaman yang mencemaskan, dan menakutkan. Situasi kecemasan dan ketakutan yang dihadirkan klien disusun secara sistematis dari yang kurang mencemaskan hingga yang paling mencemaskan. Jadi secara umum, menurut Nelson \& Jones (2005), menyatakan desensitisasi sistematis bertujuan untuk membantu klien mengendalikan dan mengurangi pengalaman negatif (seperti kecemasan, ketakutan, dan trauma) dan menggantikannya dengan perasaan yang positif sehingga dapat bertindak dan berkomunikasi secara efektif.

Prosedur teknik desensitisasi sistematis menurut Wolpe (Martin \& Peer, 2015), adalah sebagai berikut: Tahap pertama, terapis membantu klien untuk menyusun hirarki kecemasan dan atau ketakutan yang dirasakan klien dalam keadaan rileks. Hirarki kecemasan ataupun ketakutan tersebut adalah daftar pemicu yang menyebabkan klien merasa cemas atau takut yang ditulis secara berurutan mulai pemicu rasa takut atau cemas yang paling kecil hingga yang paling besar. Tahap kedua, terapis mengajarkan relaksasi otot kepada klien dengan tujuan untuk pengunduran otototot yang tegang sampai berada dalam keadaan santai. Strategi rileksasi otot ini diterapkan di semua otot dalam area utama tubuh seperti lengan, leher, bahu dan kaki. Sebelum dimulai rileksasi, terapis mengajarkan cara rileksasi yang digunakan dalam desensitisasi sistematis kepada klien yang hendak diterapi. Wolpe (1969), menjelaskan cara rileksasi agar klien berpikir santai dan terapis mengajarkan klien untuk membayangkan sebuah tempat yang membuat klien 
nyaman dan santai. Tempat atau situasi yang membuat santai seperti duduk di pinggir danau atau berjalan-jalan ditaman yang indah, sering digunakan dalam rileksasi Wolpe (dalam Corey, 2007). Prinsip rileksasi adalah agar klien merasakan tenang dan damai. Setelah klien memahami rileksasi atau telah merasa santai seutuhnya, maka tahap ketiga, terapi sesungguhnya dimulai. Tahap ketiga, teknik desensitisasi sistematis diterapkan kepada klien yang dalam posisi keadaan santai dengan mata tertutup.

Setelah tahapan telah disiapkan, terapis memberikan treatment dengan menceritakan sebuah situasi dan dimintah klien agar membayangkan dirinya berada dalam setiap situasi tersebut. Terapis akan menyesuaikan cerita dalam setiap situasi berdasarkan urutan pemicu ketakutan ataupun kecemasan. Dalam situasi cerita awal, apabilah klien masih dalam posisi santai maka klien akan diminta untuk membayangkan situasi yang membangkitkan kecemasan yang paling kecil. Terapis terus bergerak menceritakan situasi secara berurutan sampai menunjukan klien merasakan kecemasan atau ketakutan, ketika klien benar-benar merasa cemas atau takut maka di saat itupun cerita diakhiri. Kemudian relaksasi dimulai lagi sampai klien merasa rileks, setelah itu, klien kembali membayangkan dirinya berada dalam cerita tadi oleh terapis. Terapi dianggap selesai apabila klien sudah tetap santai pada situasi yang menimbulkan kecemasan atau ketakutan yang diceritakan oleh terapis (Corey, 2007).

\section{Penelitian Terdahulu Mengenai Teknik}

\section{Desensitisasi Sistematis dalam Konteks}

\section{Kecemasan Personal}

Teknik Desensitisasi sistematis telah banyak diaplikasikan terhadap kecemasan personal. Beberapa hasil penelitian terdahulu mengenai kecemasan personal dengan terapi behavioral menggunakan teknik desensitisasi sistematis, secara umum, menunjukan teknik desensitisasi sistematis terbukti efektif menurunkan tingkat kecemasan personal. Penelitian terdahulu oleh Lestari, Latief, dan Widiastuti (2013), mengenai kecemasan siswa di Sekolah dengan menggunakan teknik desensitisasi sistematis. Berdasarkan hasil perhitungan signifikansi $5 \%$ diperoleh. Penelitian ini menunjukan bahwa terjadinya penurunan 38,5 dari 129,5 menjadi 91 setelah di berikan teknik desensitisasi sistematis. Subyek berjumlah enam orang siswa yang memiliki tingkat kecemasan tinggi. Kesimpulan penelitian ini adalah kecemasan siswa di sekolah terbukti 
efektif dapat dikurangi dengan

bahwa calon mahasiswa dalam menggunakan teknik desensitisasi sistematis. Hasil penelitian terdahulu juga dilakukan oleh Febbyanti, Giyono, \& Utaminingsih (2013), mengenai kecemasan siswa pada saat presentasi menggunakan teknik desensitisasi sistematis. Berdasarkan perhitungan uji signifikansi $5 \%$ terbukti efektif menurunkan tingkat kecemasan siswa saat presentasi.

Sementara itu, bagi siswa yang mengalami kecemasan sosial juga dapat diatasi dengan teknik desensitisasi sistematis. Rachmawati (2012) melakukan penelitian mengenai kecemasan sosial siswa menggunakan teknik desensitisasi sistematis. Hasil penelitiannya terbukti dapat mengatasi kecemasan sosial yang dialami siswa. Sementara itu penelitian mengenai kecemasan calon mahasiswa dalam menghadapi seleksi bersama masuk perguruan tinggi negeri (SBMPTN) juga dapat digunakan dengan teknik desensitisasi sistematis. Seperti hasil penelitian oleh Mustika, Yusmansyah, \& Rahmayanthi (2014) mengenai kecemasan calon mahasiswa mengikuti SBMPTN, hasil penelitian mereka menunjukan teknik desensitisasi sistematis dapat mengurangi secara signifikan kecemasan yang dialami calon mahasiswa. Kesempulan penelitian ini menyatakan menghadapi SBMPTN dapat dikurangi melalui teknik desensitisasi sistematis. Selain itu, teknik desensitisasi sistematis juga dapat digunakan untuk meminimalisir kecemasan dalam menyampaikan pendapat. Hasil penelitian oleh Aryani, Suarni, Putri, dan Ps (2014), mengenai siswa yang mengalami kecemasan dalam menyampaikan pendapat menunjukan tingkat kecemasan dapat diturunkan dengan menggunakan teknik desensitisasi sistematis.

Berdasarkan beberapa hasil penelitian diatas, maka dapat disimpulkan bahwa teknik desensitisasi sistematis dapat menurunkan kecemasan personal di berbagai konteks. Penelitian mengenai kecemasan personal telah diuji oleh Joseph Wolpe sejak tahun 1952, terbukti bahwa respon kecemasan dapat dihasilkan dengan kondisioning klasik dan respon kecemasan tersebut juga dapat dihilangkan dengan metode counterconditioning. Penelitian Wolpe ini membuahkan hipotesis umum yaitu jika suatu respon yang tidak sesuai dengan kecemasan dapat diciptakan ditengah keberadaan stimulus yang membuat cemas, maka ikatan antara respon kecemasan tersebut akan menjadi lemah atau hilang. Hasil penelitian tersebut 
melahirkan teknik desensitisasi sistematis (Wolpe \& Plaud, 1997).

\section{PENUTUP}

Berdasarkan kajian literatur di atas, maka dapat disimpulkan bahwa fenomena kekerasan dalam pacaran di Indonesia jumlahnya cukup besar, dan penyintas tindakan kekerasan tersebut menimbulkan gangguan psikologis yang sangat memprihatinkan untuk itu perlu di intervensi. Salah satu metode penanganan yang telah dibahas dalam review ini adalah perspektif terapi behavioral teknik desensitisasi sistematis. Terapi ini terbukti efektif menurunkan gangguan kecemasan dalam berbagai situasi. Hakekatnya, terapi ini berfokus untuk menangani pada gangguan kecemasan, ketakutan, dan perilaku maladaptif yang dialami oleh individu. Sementara tujuannya adalah untuk menghapus atau mengurangi gangguan-gangguan tersebut agar individu dapat berpikir positif, bertindak lebih baik, dan berkomunikasi secara efektif. Teknik desensitisasi sistematis belum pernah dilakukan di Indonesia khususnya pada korban kekerasan dalam pacaran, oleh karena itu pentingnya dilaksanakan sebuah pilot study di Indonesia sesuai dengan prinsip terapi behavioral teknik desensitisasi sistematis pada perempuan penyintas kekerasan dalam pacaran.
Sebelum dilakukan intervensi teknik desensitisasi sistematis perlu memperhatikan aspek-aspek yang sesuai dengan teori ini, dan juga harus di koordinasikan dengan supervise (psikolog) agar kebutuhan dasar intervensi ini dapat dipersiapkan dengan baik.

\section{DAFTAR PUSTAKA}

Astuti. 2018. Efektivitas Konseling Behavioral dengan Teknik Desensitisasi Sistematis untuk Mengurangi Kecemasan Berkomunikasi di Depan Umum Pada Peserta Didik Kelas XII SMAN 8 Bandar Lampung Tahun Pelajaran 2018/2019. Skripsi, di terbitkan, Universitas Islam Negeri Raden Intan Lampung.

Badan Pusat Statistik. 2012. Survei demografi dan kesehatan Indonesia 2012. Jakarta: Badan Pusat Statistik.

Baldwin, K. 2012. Factbox: The worst and best G20 countries for women. Thomson Reuters Foundation. Retrieved from http://www.trust.org/item/201206 13010100sk 134/?source=spotligh $\mathrm{t}$

Corey, G. 2005. Theory and Practice Of Counseling and Psychotherapy. Seventh Edition. Belmont: Brooks/Cole-Thomson Learning.

Corey, G. 2007. Teori dan praktek konseling \& psikoterapi. Bandung: Refika Aditama. 
Ghufron, M. Nur \& Risnawati S, Rini. 2010. Teori-Teori Psikologi. Jogjakarta: AR-Ruz Media

Komnas Perempuan. 2012. Stagnansi sistem hukum: Menggantung asa perempuan korban, catatan KTP tahun 2011. Jakarta. Retrieved from

https://www.komnasperempuan.g o.id /file/pdf_file/Catatan Tahunan/10.PP5_CATAHU 2012.pdf

Mujahidah, M. 2015. Implementasi Teori Ekologi Bronfenbrenner Dalam Membangun Pendidikan Karakter Yang Berkualitas. LENTERA, 17(2).

Murray, J. 2007. But I love him: Protecting Your Teen Daughter From Controlling, Abusive Dating Relationships. New York, NY: Harper Collins.

Nelson, R., \& Jones. 2005. Pratical Counseling and Helping Skills Fifth Eition. London : Sage Publications.

Nurherwati, S. 2013. Perbincangan di Komnas Perempuan tanggal 29 Januari 2013.

Poerwandari, K. 2004. Mengungkap selubung kekerasan: Telaah filsafat manusia. Bandung: Kepustakaan Eja Insani.

Santrock, J. W. 2013. Life Span Development. New York: The McGraw-Hill Companies.
Sanyata, S. 2012. Teori dan Aplikasi Pendekatan Behavioristik dalam Konseling. Jurnal Paradigma, 14(7), 1-11.

UNICEF. 2016. Child marriage in Indonesia: Progress on pause. Retrieved from https://www.unicef.org/indonesia/ UNICEF_Indonesia_Child_Marri age_Reserach_Brief_pdf

Vagi, K. J., Rothman, E. F., Latzman, N. E., Tharp, A. T., Hall, D. M., \& Breiding, M. J. 2013. Beyond correlates: A review of risk and protective factors for adolescent dating violence perpetration. Journal of Youth and Adolescence, 42(4), 633-649. doi: 10.1007/s10964-013-9907-7

Willis, Sofyan. 2004. Konseling Individual Teori dan Praktek. Bandung: Alfabeta.

World Health Organization. 2013. Global And Regional Estimates of Violence Against Women: Prevalence And Health Effects Of Intimate Partner Violence And Non-Partner Sexual Violence. Retrieved from http://www.who.int/reproductive health/publications/violence/9789 241564625/en/

Yayasan Pulih. 2015. Love without violence: Relasi sehat vs kekerasan dalam pacaran [Booklet Psikoedukasi Remaja]. Jakarta: Yayasan Pulih. 